\title{
Effects of Valproic Acid on $\beta$-adrenergic Receptors, G-proteins, and Adenylyl Cyclase in Rat C6 Glioma Cells
}

Guang Chen, M.D., Husseini K. Manji, M.D., Clinton B. Wright, B.S., David B. Hawver, Ph.D., and William Z. Potter, M.D., Ph.D.

Valproic acid (VPA) is an anticonoulsant drug with demonstrated efficacy in the treatment of mania. In the present study, we found that chronic exposure of rat $C 6$ gliona cells to VPA induces a coordinate decrease in multiple components of the $\beta$-adrenergic receptor- $(\beta-A R)$ coupled cyclic adenosine 3'-5'monophosphate (cAMP) generating system. Chronic VPA decreased the number of $\beta$-ARs in a time-and concentration-dependent manner; the decrease of $\beta$-ARs was largely $\beta_{T}$-AR selective and affected $\beta$-ARs in both the high-and lowe-affinity states. Chronic

KEY WORDS: Valproic acid; $\beta$-adrenergic receptor; Guaninenucleotide-binding protein; Adenylyl cyclase; Protein kinase C; Anticonculsant; lithium; Bipolar affectioe disorder

Valproic acid (VPA) is a broad-spectrum anticonvulsant drug with demonstrated efficacy in the treatment of manic-depressive illness (Bourgeois 1989; Bowden et al. 1994). Whereas the anticonvulsant effects of VPA are usually observed quite rapidly, its therapeutic effects in the treatment of manic-depressive illness require chronic

From the Molecular Pathophvsiology Program (GC, HKM), Schizophrenia and Mood Disorders Clinical Research Program, Department of Psychiatry and Behavioral Neurosciences, Wayne State Lniversity School of Medicine, Detroit, MI; and the Section on Clinical Pharmacology (CBW, DBH, WZP), Experimental Therapeutic Branch, National Institute of Mental Health, National Institutes of Health, Bethesda, MD.

Address correspondence to: Guang (hen, M.D., Department of Psychiatry and Beharioral Neurosciences, Wayne State University School of Medicine, 23019 Scott Hall, 540 East Canfield Avenue, Detroit, MI 48201.

Received April 19, 1995; revised September 22, 1995; accepted September 26, 1995.
VPA also significantly attenuated receptor-and postreceptor-stimulated cAMP production, $\left[{ }^{3} H\right]$ forskolin binding sites, immunolabeling of $G \alpha_{s} 45$, and cholera toxin catalyzed ADP-ribosylation of $G \alpha, 52$ and 45. Although the precise underlying mechanisms remain to be elucidated, such profound long-term changes in the functioning of this key signaling pathway may help explain the antimanic effects of chronic VPA treatment and are worthy of further study. [Neuropsychopharmacology 15:271-280, 1996]

administration with a lag time of onset of action varying from days to 2 weeks. The anticonvulsant effects of VPA have been postulated to involve its biochemical actions on voltage-dependent $\mathrm{Na}^{+}$channels and/or inhibitory and excitatory amino acid systems (Rogawski and Porter 1990; Löscher 1993). The mechanisms underlying the antimanic effects of VPA have not yet been elucidated, but have been postulated to involve biochemical effects observed after chronic, but not acute, administration (Post et al. 1992).

The etiology of manic-depressive (or bipolar) illness is unknown, but several lines of evidence suggest that dysregulation of the noradrenergic system may be involved in the pathophysiology of the illness (Potter et al. 1987; Manji et al. 1995a). Considerable progress has also been made in recent years in elucidating the mechanisms of action of lithium, which is the most effective treatment for reducing both the frequency and severity of recurrent affective episodes (reviewed in Goodwin and Jamison 1990). In contrast to chronic administration of antidepressant drugs, lithium does not affect the density of most neurotransmitter receptors (Bunney and 
Garland-Bunney 1987) but has been demonstrated to significantly attenuate $\beta$-adrenergic receptors ( $\beta$-AR) mediated cyclic AMP (cAMP) accumulation both in vivo and in vitro. These effects of lithium have generally been attributed to an effect at the level of the interaction of the receptor with the stimulatory G-protein (Gs) (Newman and Belmaker 1987; Mork and Geisler 1989a, 1989b; Manji 1992). However, postreceptor stimulation of adenylyl cyclase (AC) (e.g., with forskolin, fluoride, or nonhydrolyzable analogues of GTP) has also been shown to be inhibited by lithium in slices and membranes from rat cerebral cortices (Andersen and Geisler 1984; Geisler et al. 1985; Mork and Geisler 1987; Newman and Belmaker 1987). These results suggest that lithium may also affect postreceptor sites in the CAMP-generating system. Interestingly, the effects of chronic lithium on inhibition of $\beta$-AR-stimulated cAMP production persist after washing of the membranes and are reversed by increasing concentrations of guanosine 5 '-triphosphate (GTP) (Mork and Geisler 1989b), suggesting that the physiologically relevant effects of lithium (that is those on chronic drug administration, and not reversed immediately upon drug discontinuation) may be exerted at the level of signal-transducing G-proteins at a GTP responsive step. It is also noteworthy that elevated levels of $G \alpha_{s}$ have been observed both in postmortem brain tissue (Young et al. 1993) and in peripheral cells (Young et al. 1994; Manji et al. 1995a) from subjects with bipolar affective disorder. Increased forskolin-stimulated cAMP production in postmortem brain has also been reported (Young et al. 1993). These studies, although preliminary, suggest that alterations in the levels and/or function of certain G-proteins and adenylyl cyclases may underlie the pathophysiology of bipolar affective disorder and as such may represent targets for drugs used in the treatment of the disorder.

Given the clinical efficacy of VPA in the treatment of manic-depressive illness, we undertook the present study to determine whether VPA affects similar targets as lithium, focusing on components of the $\beta$-AR-coupled cAMPgenerating system. We chose cultured rat $\mathrm{C} 6$ glioma cells for our studies because the components of the $\beta$-AR-coupled cAMP-generating system have been well characterized in these cells (Fishman and Finberg 1987; Manji et al. 1992) and because chronic incubation of these cells with VPA (up to $1 \mathrm{mM}$ ) does not have any cytotoxic effects (Martin and Regan 1988), thereby making them a suitable model for the study of chronic drug effects. We examined the effects of VPA on dynamic $\beta$-AR-binding parameters, receptor- and postreceptor-stimulated cyclic AMP accumulation, and forskolin binding sites. In addition, we quantitated the levels of the G-protein $\alpha$ subunits mediating the stimulation and inhibition of adenylyl cyclase $\left(G \alpha_{s}\right.$, and $G\left(x_{1-2}\right.$, respectively), as well as the levels of $\mathrm{G} \alpha_{\mathrm{q} / 11}$ and $\mathrm{G} \alpha_{0}$ that regulate the stimulation of phosphoinositide turnover and $\mathrm{Ca}^{+-}$chan- nels, respectively. We find that chronic, but not acute, incubation of rat C6 glioma cells with VPA produces a coordinate attenuation at various levels of $\beta$-AR-coupled cAMP-generating system.

\section{MATERIALS AND METHODS}

\section{Cell Culture and Treatment}

Rat $C_{6}$ glioma cells (American Type Culture Collection) were cultured in Dulbecco's Modified Eagle's Medium (DMEM) supplemented with $5 \%$ fetal bovine serum at $37^{\circ} \mathrm{C}$ in an atmosphere of $95 \%$ air and $5 \% \mathrm{CO}_{2}$ (Manji et al. 1991). Confluent cultures were subcultured at a ratio of 1:20 and incubated with vehicle (DMEM) or sodium valproate (dissolved in DMEM). In the chronic incubation study, the culture media was changed every 3 to 4 days. To rule out the potential toxic effects of the concentrations of VPA used, the cells were evaluated by microscopic examination for possible morphological changes, total cell numbers were counted using a coulter counter, and total protein concentration was determined by the method of Bradford (1968).

\section{及-AR Binding Parameters}

Cell surface $\beta$-AR binding was performed using established methods (Fishman and Finberg 1987). In brief, after cells were cultured in $35-\mathrm{mm}$ Petri dishes overnight, they were washed with $2 \mathrm{~mL}$ of DMEM and then incubated in $1 \mathrm{~mL}$ of DMEM containing $30 \mu \mathrm{g}$ of bovine serum albumin and $2 \mathrm{nM}$ of $\left[{ }^{3} \mathrm{H}\right] \mathrm{CGP}-12177$ at $37^{\circ} \mathrm{C}$ for 1.5 hours. The reaction was stopped by aspirating the DMEM medium containing the radioligand and then washing three times with $2 \mathrm{~mL}$ of ice-cold wash buffer containing $20 \mathrm{mM}$ HEPES ( $\mathrm{pH}$ 7.5), $137 \mathrm{mM} \mathrm{NaCl}, 4$ $\mathrm{mM} \mathrm{KCl}, 0.6 \mathrm{mM} \mathrm{MgCl} 2$, and $0.3 \mathrm{mM} \mathrm{CaCl}_{2}$. The cells were lysed by the addition of $\mathrm{NaOH}(0.2 \mathrm{~N})$, and the cell lysates were assayed for tritium activity using a scintillation counter at a counting efficiency of approximately $60 \%$. Nonspecific binding was determined using $2 \mathrm{mM}$ propranolol and usually represented less than $30 \%$ of total binding.

For membrane $\beta$-AR-binding assays, $\mathrm{C} 6$ cells were suspended and lysed in a binding buffer containing 50 $\mathrm{mM}$ Tris- $\mathrm{HCl}$ ( $\mathrm{pH}$ 7.4), $2.5 \mathrm{mM} \mathrm{MgCl}_{2}$ and $1 \mathrm{mM}$ ethylene diaminetetraacetic acid (EDTA) following three washes with $10 \mathrm{ml}$ of $\mathrm{Ca}^{++}$and $\mathrm{Mg}^{++}$-free phosphate buffered saline. After polytron homogenization, the cell homogenate was centrifuged at $300 \times \mathrm{g}$ for 12 minutes, and the supernatant was then centrifuged at $49,000 \times \mathrm{g}$ for 30 minutes to yield the membrane fraction.

Saturation experiments were carried out using 5-75 pM ${ }^{125}$ I-iodocyanopindolol ([ $\left.\left.{ }^{125} \mathrm{I}\right] \mathrm{ICYP}\right)$ to determine total binding sites $\left(B_{\max }\right)$ and the dissociation constant $\left(K_{\mathrm{d}}\right)$ of $\beta$-ARs for the ligand, as described previously (Manji 
et al. 1991). The relative numbers of $\beta_{1}$-ARs and $\beta_{2}$-ARs were determined by steady-state competition of 18 different concentrations of the cold $\beta_{2}-A R$ antagonist ICI $118.551\left(10^{-10}\right.$ to $\left.10^{-4} \mathrm{M}\right)$ for $\left[{ }^{125} \mathrm{I}\right] \mathrm{IC} Y \mathrm{P}(50 \mathrm{pM})$ binding sites (Tiong and Richardson 1991). The proportions of receptors in the high- and low-affinity conformations were determined by steady-state competition of 18 different concentrations of the $\beta$-agonist isoproterenol $\left(10^{-10}\right.$ to $\left.10^{-+} \mathrm{M}\right)$ with a fixed concentration of ${ }^{125}$ ICYP $(20 \mathrm{pM})$ (Manji et al. $1991 \mathrm{a}$ and b). The [125I]ICYP binding data were analyzed by the program LIGAND (Munson 1983) and showed that a one-site model provided the best fit for the saturation curve and that a two-site model provided the best fit for the competition curves.

\section{cAMP Determinations}

Intracellular cAMP accumulation was determined largely according to previously described methods (Manji et al. 1991). In brief, the cells were grown in 24 well trays and incubated with DMEM containing $30 \mu \mathrm{M}$ rolipram (a nonmethylxanthine phosphodiesterase inhibitor) at $37^{\circ} \mathrm{C}$ for 10 minutes. The cells were then incubated for an additional 15 minutes with varying concentrations of isoproterenol (ISO) or forskolin. Reactions were stopped by the removal of the buffer and the addition of $1.0 \mathrm{ml} 0.1$ $\mathrm{N} \mathrm{HCl}$. After 30-minutes, the $\mathrm{HCl}$ was neutralized, and cAMP levels were determined by a commercially available cAMP assay kit (Amersham, Arlington Heights, IL).

$\mathrm{MnCl}_{2}$-stimulated cAMP production was determined in cell membranes largely according to the methods of Tang and Gilman (1991) with minor modifications. In brief, C6 cell membranes were prepared as described in a cAMP assay buffer containing $50 \mathrm{mM}$ Tris- $\mathrm{HCl}(\mathrm{pH}$ 7.5), $10 \mathrm{mM} \mathrm{MgCl} 2,1 \mathrm{mM}$ dithiothreitol, and $30 \mu \mathrm{M}$ rolipram. The cell membranes $(20 \mu \mathrm{g})$ were then stimulated by $\mathrm{MnCl}_{2}(80 \mathrm{mM})$ at $25^{\circ} \mathrm{C}$ for 30 minutes in $100 \mu \mathrm{l}$ cAMP assay buffer containing $25 \mu \mathrm{M}$ adenosine 5 '-triphosphate. The reaction was terminated by the addition of $0.1 \mathrm{HCl}$, which was subsequently neutralized with $\mathrm{NaOH}$. The cAMP levels were determined using a commercially available cAMP assay kit (Amersham, Arlington Heights, IL).

\section{Immunoblotting and Toxin Catalyzed [32P]ADP-ribosylation}

To assess VPA's effects on the levels of G-protein $\alpha$ subunits, $\mathrm{C} 6$ cell membranes were prepared as described in a lysing buffer containing $20 \mathrm{mM}$ Tris- $\mathrm{HCl}$ ( $\mathrm{pH} 7.4) 2 \mathrm{mM}$ EGTA, $0.5 \mathrm{mM}$ EDTA, $10 \mathrm{mg} / \mathrm{ml}$ leupeptin, $10 \mathrm{mg} / \mathrm{ml}$ aprotinin, and $0.2 \mathrm{mM}$ phenylmethylsulfonyl fluoride. G-protein $\alpha$ subunit immunoblotting was performed largely as previously described (Masana et al. 1992), using membrane protein concentrations demonstrated to be within the linear range for Western blotting. In brief, 20 to 40 $\mu \mathrm{g}$ of $\mathrm{C} 6$ membrane protein was loaded per well and separated on $10 \%$ polyacrylamide gels according to the method of Laemmli (1970). Proteins resolved on the gel were then electrophoretically transferred to nitrocellulose membranes. Nonspecific binding on the nitrocellulose was blocked with low-detergent "blotto" containing $50 \mathrm{mM}$ Tris ( $\mathrm{pH} 8.0$ ), $2 \mathrm{mM} \mathrm{CaCl}_{2}, 80 \mathrm{mM} \mathrm{NaCl}, 5 \%$ nonfat dry milk, $0.2 \% \mathrm{NP}-40$, and $0.02 \% \mathrm{NaN}_{3}$. Blots were then incubated at room temperature overnight with polyclonal anti-G $\alpha_{\mathrm{s}}$, anti-G $\alpha_{i 1-2}$, anti-G $\alpha_{\mathfrak{q}} / 11$, or anti-G $\alpha_{\mathrm{o}}$ antiserum. The antibodies for all G-protein $\alpha$ subunits were diluted 1:1000 in low-detergent "blotto" prior to use. Blots were washed three times, and the nitrocellulose sheets were then incubated with $1 \times 10^{6} \mathrm{cpm}\left[{ }^{125} \mathrm{I}\right]$ protein A (Amersham, Arlington Heights, IL) for 1 hour. The blots were subsequently washed, dried, and exposed to $x$-ray film with intensifying screens at $-80^{\circ} \mathrm{C}$. Quantitation of immunoblots was performed by densitometric scanning of the autoradiograms using the NIH image 1.42 analysis system. An aliquot of pooled "standard" C6 membranes was run on one lane of each gel (to normalize for between-blot variability), and the immunolabeling was calculated relative to this standard. Using these methods, the intrablot and interblot coefficients of variation have been estimated to be $4 \%$ to $8 \%$ and $10 \%$ to $15 \%$, respectively.

Cholera and pertussis toxin catalyzed labeling of C6 cell membranes was performed using previously described methods (Hsiao et al. 1992; Manji et al., 1995a). The linearity of the membrane protein concentration for cholera and pertussis toxin catalyzed [ $\left.{ }^{32} \mathrm{P}\right]$ labeling was previously ascertained by resolution of selected concentrations of membrane protein (between 20 and $400 \mu \mathrm{g}$ ); subsequent studies were performed using protein concentrations $(100 \mu \mathrm{g})$ known to be within the linear range for both cholera and pertussis toxin catalyzed [32P]labeling. In brief, $100 \mu \mathrm{g}$ of membrane protein was added to $60 \mu \mathrm{l}$ of solution consisting of $12.5 \mathrm{mM}$ Tris $\mathrm{HCl}(\mathrm{pH}$ 7.5), $10 \mathrm{mM}$ thymidine, $1 \mathrm{mM}$ ATP, $1 \mathrm{mM} \mathrm{GTP}, 1 \mathrm{mM}$ EDTA, $10 \mathrm{mM} \mathrm{MgCl}_{2}$ (for cholera toxin), $10 \mu \mathrm{M}$ nicotinamide adenine dinucleotide (NAD), and $63 \mathrm{nM}$ [32 P]NAD $(800 \mathrm{Ci} / \mathrm{mmol})$. The reaction was started by the addition of the toxin mixture containing either 48 $\mu \mathrm{g}$ of cholera toxin $(10 \mu \mathrm{l})$ or $1.2 \mu \mathrm{g}$ of pertussis toxin $(10 \mu \mathrm{l})$, which had been preactivated. The toxin catalyzed ribosylation reaction was carried out at $37^{\circ} \mathrm{C}$ for 45 minutes. The toxins were activated by incubation at $37^{\circ} \mathrm{C}$ for 30 minutes in the presence of $10 \mathrm{mM}$ dithiothreitol (DTT) and $0.4 \mu \mathrm{M} 5$ '-adenylylimidodiphosphate (for pertussis toxin), or $0.04 \%$ of SDS (for cholera toxin). The activated toxin was then diluted with $75 \mathrm{mM}$ Tris $\mathrm{HCl}$ (pH 7.5 and $0.05 \%$ of bovine serum albumin. Cholera and pertussis toxin catalyzed [ $\left.{ }^{32} \mathrm{P}\right] \mathrm{ADP}$-ribosylation of all samples was performed in duplicate. Labeled membranes were washed in ice-cold buffer, and proteins were solubilized and subjected to $10 \%$ poly- 
acrylamide gels using the method of Laemmli (1970). The gels were dried and exposed to an x-ray film (Kodak X-omat, Rochester, NY) with an intensifying screen at $-80^{\circ} \mathrm{C}$. Estimation of the molecular weights of labeled protein bands was made by comparison with molecular weight standards. An aliquot of pooled "standard" C6 cell membranes was run on one lane of every gel, and the quantitation of [ $\left.{ }^{32} \mathrm{P}\right]$ incorporation was calculated relative to this standard.

\section{[ $\left.{ }^{3} \mathrm{H}\right]$ forskolin Binding}

C6 cell membranes were prepared as described in a binding buffer containing $50 \mathrm{mM}$ Tris- $\mathrm{HCl}, 5 \mathrm{mM} \mathrm{MgCl} 2,0.1$ $\mathrm{mM}$ EDTA, $1 \mathrm{mM}$ dithiothreitol, $10 \mu \mathrm{g} / \mathrm{ml}$ leupeptin and $10 \mu \mathrm{g} / \mathrm{ml}$ aprotinin. $\left[{ }^{3} \mathrm{H}\right]$ forskolin binding was performed largely according to previously described methods (Laurenza and Seamon 1991) with minor modifications. The binding reaction was conducted in triplicate at $25^{\circ} \mathrm{C}$ for 1 hour in $125 \mu \mathrm{l}$ of binding buffer containing 20-25 $\mu \mathrm{g}$ membrane protein, $100 \mathrm{nM}\left[{ }^{3} \mathrm{H}\right]$ forskolin, and $2 \mathrm{mM}$ $\mathrm{NaF}$. Nonspecific binding of $\left[{ }^{3} \mathrm{H}\right]$ forskolin was determined in the presence of $10 \mu \mathrm{M}$ nonradiolabeled forskolin. The binding reaction was stopped by the addition of $5 \mathrm{ml}$ ice-cold $50 \mathrm{mM}$ Tris- $\mathrm{HCl}$ ( $\mathrm{pH} 7.5)$, following which the unbound $\left[{ }^{3} \mathrm{H}\right]$ forskolin was separated by filtration through Whatman GF/B filter paper. The filter paper was then washed twice with $5 \mathrm{ml}$ ice-cold $50 \mathrm{mM}$ Tris$\mathrm{HCl}$, and the level of $\left[{ }^{3} \mathrm{H}\right]$ on filter paper was determined using a scintillation counter with a counting efficiency of approximately $60^{\circ} \%$.

\section{Chemicals and Statistical Analyses}

[ $\left.\left.{ }^{3} \mathrm{H}\right] \mathrm{CGP}-12177, \alpha-{ }^{3} 2 \mathrm{P}\right] \mathrm{NAD},\left[{ }^{125}\right] \mathrm{ICY},\left[{ }^{3} \mathrm{H}\right]$ forskolin, and G-protein $\alpha$ subunit antibodies were from Dupont (Wilmington, DE); (-)-ISO was from Sigma chemical Company (St. Louis, MO, USA); [ $\left.{ }^{125} I\right]$ protein A was from Amersham (Arlington Heights, IL). Forskolin, ICl 118.551, and sodium valproate were from Research Biochemicals Incorporated (Natick, MA). The Bio Rad protein assay kit was from Bio Rad (Bio RAD, Richmond, CA), and bovine serum albumin was used in protein assay as standard. Data are expressed as mean \pm SE. A two-tailed Student's $t$ test or one-factor analysis of variance (ANOVA) for independent samples was used for statistical analyses of difference between two groups or differences among multiple groups.

\section{RESULTS}

We previously reported that incubation of $\mathrm{C} 6$ glioma cells with VPA $(0.2-0.7 \mathrm{mM})$ for up to 6 days did not produce any toxic effects as assessed by microscopic exam- ination of cell morphology, cell numbers, or protein content (Chen et al. 1994).

\section{Effects of VPA on $\boldsymbol{\beta}$-AR Binding Parameters}

$\left[{ }^{3} \mathrm{H}\right] \mathrm{CGP}-12177$ binding assay was conducted using intact cells. Incubation of the cells with $0.5 \mathrm{mM}$ of VPA for 1 to 7 days resulted in significant decreases in [ $\left.{ }^{3} \mathrm{H}\right] \mathrm{CGP}-$ 12177 binding sites in a time-dependent manner (Fig. 1A). Similarly, incubation of $\mathrm{C} 6$ cells with 0.175 to 1.4 $\mathrm{mM}$ of VPA for 6 days produced a concentration-dependent decrease in [ $\left.{ }^{3} \mathrm{H}\right] \mathrm{CGP}-12177$ binding (Fig. 1B). The inclusion of VPA $(0.175-1.4 \mathrm{mM})$ in the biriding assay had no effect on the binding results (data not shown).

[125]|ICYP binding assay was performed using cell membranes. A one-site model provided the best fit for the [125]]ICYP saturation curve. VPA at concentrations of 0.01 to $10 \mathrm{mM}$ did not displace [ ${ }^{125}$ I]ICYP binding to $\beta$-ARs (data not shown). The $K_{d}$ values of $\beta$-ARs for [ ${ }^{125}$ I]ICYP were similar in the control membranes and in the membranes prepared from cells incubated with VPA $(0.5 \mathrm{mM})$ for 6 days (data not shown), and the values were also similar to those previously reported in C6 glioma cells (Fishman and Finberg 1987; Manji et al. 1991a). However, 6-day incubation of C6 glioma cells with VPA $(0.5$ $\mathrm{mM}$ ) resulted in a $33 \%$ reduction in $B_{\max }$ (Table 1 ).

The numbers $\left(\beta_{\mathrm{H}}\right.$ and $\left.\beta_{\mathrm{I}}\right)$ and the affinities $\left(K_{\mathrm{H}}\right.$ and $K_{L}$ ) of membrane $\beta$-ARs in both the high-and low-affinity states were determined by agonist ISO competition experiments using [ [25I]ICYP as the radiolabeled ligand. A two-site model provided the best fit for the competition curve; we found that approximately $53 \%$ of membrane $\beta$-ARs were in the high-affinity state, which is similar to what we have previously noted in the same cell line (Manji et al. 1991a). Incubation of C 6 cells with 0.5 $\mathrm{mM} V \mathrm{PA}$ for 6 days did not significantly alter either $K_{H}$ and $K_{\mathrm{I}}$, but reduced both $\beta_{\mathrm{H}}$ and $\beta_{\mathrm{I}}$ by approximately $35 \%$ (Table 1$)$. The numbers $\left(\beta_{1}\right.$ and $\left.\beta_{2}\right)$ and affinities $\left(K_{1}\right.$ and $\left.K_{2}\right)$ of membrane $\beta_{1}$-ARs and $\beta_{2}$-ARs were determined separately using ICI 118.551 in competition experiments with [ $\left.{ }^{125} \mathrm{I}\right] \mathrm{ICY} P$ as the radiolabeled ligand. A two-site model provided the best fit for the competition curve. Approximately $69 \%$ of $\beta$-ARs was found to be of the $\beta_{1}$ subtype. Incubation of $C 6$ cells with $0.5 \mathrm{mM}$ VPA for 6 days did not alter $K_{1}$ and $K_{2}$ (data not shown), but resulted in a marked and selective $41 \%$ reduction of $\beta_{1}$, without having significant effects on $\beta_{2}$ (Table 1).

\section{Effects of VPA on cAMP Production}

To examine whether the decreases in the density of $\beta$-ARs were accompanied by alterations in cAMP levels, we initially conducted dose-response studies with isoproterenol, forskolin, and $\mathrm{MnCl}_{2}$ to determine the concentrations producing the maximal cAMP response in $\mathrm{C} 6$ cells; subsequent studies examining the effects of chronic VPA uti- 


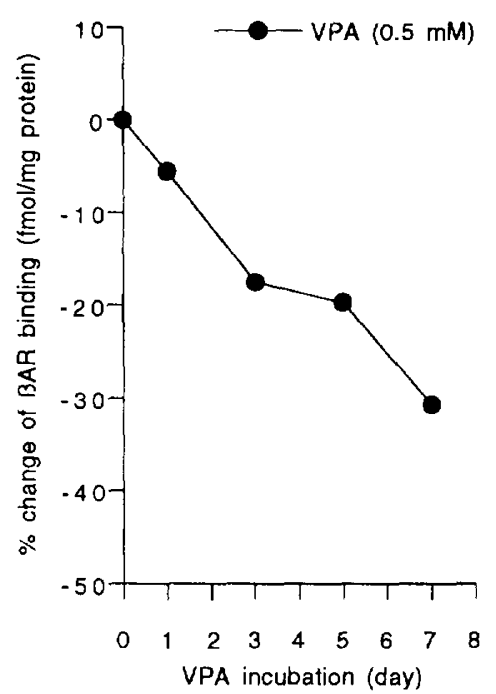

B

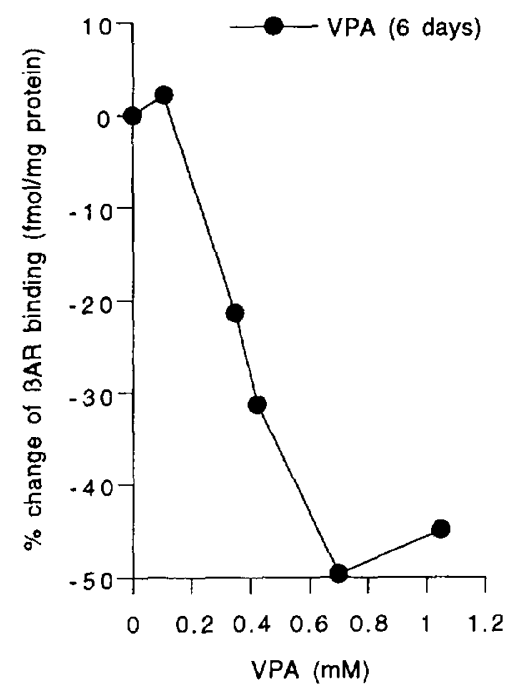

Figure 1. Effects of VPA on cell surface $\beta$-ARs: Time and concentration dependence. Rat C 6 glioma cells were cultured in DMEM and incubated with $0.5 \mathrm{mM}$ VPA for the times indicated (A) or with VPA at the concentrations indicated for 6 days (B). The intact cells were then washed with fresh serum-free DMEM and assayed for [ $\left.{ }^{3} \mathrm{H}\right] \mathrm{CGP}-12171$ binding to cell surface $\beta$-ARs as described in Materials and Methods. $2 \mathrm{nM}$ of $\left[{ }^{3} \mathrm{H}\right]$ CGP-12171 was used in all of binding assays. Values are the means of triplicates of one experiment. Similar results were also obtained from two or more additional experiments.

lized concentrations of ISO- $(10 \mu \mathrm{M})$ and $\mathrm{MnCl}_{2}(8 \mathrm{mM})$ that produced the maximal CAMP response. Forskolin dose-dependently increased cAMP accumulation, but we chose not to exceed concentrations above $100 \mu \mathrm{M}$ because of the compound's relative insolubility at higher concentrations.

Chronic (6-day) incubation of C 6 cells with VPA $(0.5$ $\mathrm{mM}$ ) reduced basal levels of CAMP by approximately $20 \%$ in intact cells and by $35^{\circ}$, in cell membranes (Table 2). Chronic (6-dav) VPA $(0.5 \mathrm{mM})$ incubation also markedly attenuated ISO- $(10 \mu \mathrm{M})$ and forskolin- $(100 \mu \mathrm{M})$ stimulated cAMP production in intact cells by about $50 \%$ and $60 \%$, respectively (Table 2 ). Incubation of C6 cells with VPA $(0.5 \mathrm{mM})$ also attenuated the increase in the levels of $\mathrm{CAMP}$ in response to $\mathrm{MnCl}_{2}(8 \mathrm{mM})$ by approximately $48 \%$ (Table 2$)$. The inclusion of VPA $(0.5$
$\mathrm{mM}$ ) in the assay mixture had no effect on either basal or stimulated cAMP production (data not shown).

\section{Effects of VPA on G Proteins}

As can be seen in the representative autoradiogram (Figure 2), all four polyclonal G-protein antisera used selectively recognized distinct $G$-protein $\alpha$ subunits as previously described (Hsiao et al. 1992; Simonds et al. 1993; Manji et al. 1995a). Thus, the $G \alpha_{s}$ antiserum recognized a major band migrating on the gel with an apparent molecular mass of $52 \mathrm{kDa}$ and a smaller band migrating at $45 \mathrm{kDa}$; the $\mathrm{G} \alpha_{112}, \mathrm{G} \alpha_{\mathrm{q} / 11}$, and $\mathrm{G} \alpha_{0}$ antisera all recognized a single band with an apparent molecular mass of 40 to $42 \mathrm{kDa}$. As can be seen in Figures 2 and 4, long-term ( 3 or more days), but not short-term (1-day) incubation of

Table 1. Effects of Chronic VPA on Cell Number, I'rotein Content and $\beta-A R$ Binding Parameters in Rat C6 Glioma Cells

\begin{tabular}{lcc} 
& Control & VPA \\
\hline Cell number $\left(\times 10^{6}\right.$ ctlls/flask) & $40.39 \pm 1.28$ & $39.97 \pm 1.17$ \\
Protein content $(\mathrm{mg} / \mathrm{flask})$ & $15.26 \pm 0.71$ & $15.35 \pm 0.44$ \\
Density of $\beta-\mathrm{AR}(\mathrm{fmol} / \mathrm{mg}$ protein) & $1545.9 \pm 226.1$ & $1082.2 \pm 105.2^{*}$ \\
Density of $\beta_{\mathrm{I}}-\mathrm{AR}(\mathrm{fmol} / \mathrm{mg}$ protein) & $1032.2 \pm 140.5$ & $608.9 \pm 80.4^{*}$ \\
Density of $\beta$ - $\mathrm{AR}(\mathrm{fmol} / \mathrm{mg}$ protein) & $466.9 \pm 76.5$ & $430.1 \pm 67.2$ \\
Density of $\beta \mathrm{H}-\mathrm{AR}(\mathrm{fmol} / \mathrm{mg}$ protein) & $690.7 \pm 43.5$ & $458.2 \pm 49.8^{*}$ \\
Density of $\beta \mathrm{L}-\mathrm{AR}(\mathrm{fmol} / \mathrm{mg}$ protein) & $590.1 \pm 70.9$ & $390.5 \pm 39.2^{*}$ \\
\hline
\end{tabular}

Rat Co glioma cells were cultured in DMEM in the absence or presence of 0.5 or $0.6 \mathrm{mM}$ VPA for 6 days Coll number, protein content determinations, and $\beta-A R$ binding assass were performed as described in $M a-$ terials and Methods. V'alues are mean \pm SE for three or four experiments. ${ }^{*}, \ldots 5$ compared to control. 
Table 2. Effects of Chronic VPA on cAMP Production in Rat C6 Glioma Cells

\begin{tabular}{llrr} 
& & Control & VPA \\
\hline Intact cells & & & \\
$\quad$ Basal & $(\mathrm{fmol} / \mathrm{min} / \mathrm{mg}$ protein) & $514.3 \pm 44.5$ & $410.2 \pm 20.0^{* *}$ \\
ISO & $(\mathrm{pmol} / \mathrm{min} / \mathrm{mg}$ protein) & $455.8 \pm 61.7$ & $220.0 \pm 20.8^{*}$ \\
$\quad$ Forskolin & $(\mathrm{pmol} / \mathrm{min} / \mathrm{mg}$ protein) & $+65.1 \pm 59.7$ & $180.7 \pm 18.5^{*}$ \\
Cell membrane & & & \\
$\quad$ Basal & $(\mathrm{fmol} / \mathrm{min} / \mathrm{mg}$ protein) & $8.2 \pm 0.9$ & $5.3 \pm 0.7^{*}$ \\
$\mathrm{MnCl} 2$ & $(\mathrm{fmol} / \mathrm{min} / \mathrm{mg}$ protein) & $22.2 \pm 1.5$ & $12.6 \pm 1.7^{*}$ \\
\hline
\end{tabular}

Rat Co glioma cells were cultured in DMEM in the absence or presence of $0.5 \mathrm{mM}$ VPA for 6 days. Basal, $150-(10 \mu . \mathrm{M})$ and forkolin- $(10() \mu \mathrm{M})$ stimulated (AMP production were determined in intact cells, and MnCl $1_{2}-$ timulated CAMP production was determined in membranes. Assays were performed as described in Materials and Methods. Values are mean $\pm S E$ for three or four experiments. ${ }^{*}, p$.05 compared to control; **,, . 1 compared to control.

C6 glioma cells with VPA $(0.5 \mathrm{~m} . \mathrm{M})$ resulted in a very selective decrease in the immunolabeling of $G \alpha_{s} 45$, without significantly affecting the immunolabeling of any of the other G-protein $\alpha$ subunits (Figures 2 and 4).

Cholera toxin and pertussis toxin catalyzed reactions that resulted in [32P|ADP ribosylation of $G \alpha_{s}$ or $G\left(\alpha_{i} /\right.$, , respectively. As can be seen in Figures 3 and 4, chronic incubation of $\mathrm{C} 6$ cells with VPA $(0.5 \mathrm{mM})$ resulted in a significant decrease in the cholera toxin-catalyzed [32P]ADP-ribosylation of $\mathrm{G} \alpha, 45$, which was also apparent after 3 days of VPA incubation. Chronic incubation of $\mathrm{C} 6$ cells with VPA $(0.5 \mathrm{mM})$ for 3 or more days also resulted in a significant reduction in the cholera toxincatalyzed [.32P]ADP-ribosylation of $\mathrm{G} \alpha, 52$ (Figures 3 and 4). The pertussis toxin-catalyzed [3-P]ADP-ribosylations of $G\left(x_{i} / 0\right.$ were not altered at any time point studied (Figures 3 and 4 ).

\section{Effect of VPA on $\left[{ }^{3} \mathbf{H}\right]$ forskolin Binding}

Chronic (6-day) incubation of C6 cells with VPA (0.5 $\mathrm{mM})$ resulted in a $46 \%$ decrease in membrane $\left[{ }^{3} \mathrm{H}\right]$ forskolin binding sites (control: $276.0 \pm 26.4 \mathrm{fmol} / \mathrm{mg}$ protein; VPA: $148.6 \pm 14.0 \mathrm{fmol} / \mathrm{mg}$ protein; $p<.01)$. Including VPA $(0.5 \mathrm{mM})$ in the binding mixture did not alter $\left[{ }^{3} \mathrm{H}\right]$ forskolin binding (data not shown).

\section{DISCUSSION}

We have shown that chronic VPA produces significant alterations of the $\beta$-AR-coupled CAMP-generating system in C6 glioma cells. These effects were observed at concentrations of VPA similar to those attained in the plasma in the clinical treatment of neuropsychiatric dis-

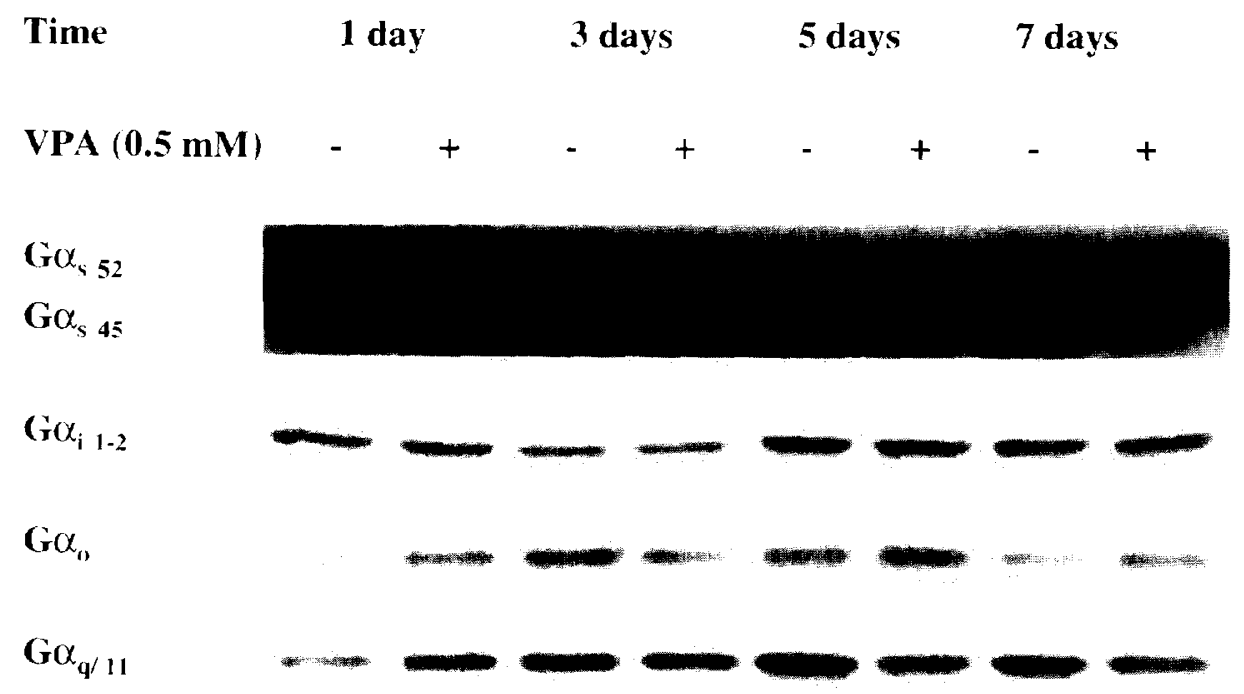

Figure 2. Effects of chronic VPA on the immunolabeling of G-protein $\alpha$ subunits. Rat C6 glioma cells were cultured in DMEM and incubated with $0.5 \mathrm{mM}$ VPA for the times indicated. Cells were washed, and cell membranes were prepared as described. Western blotting of $G$-protein $\alpha$ subunits $\left(G_{s}, 52, G_{s} 45, G_{i 1-2}, G_{4 / 11}\right.$, and $\left.G_{0}\right)$ was performed using selective polyclonal antibodies. Similar results were also obtained from two or more additional experiments. 


\begin{tabular}{|c|c|c|c|c|}
\hline Time & 1 day & 3 days & 5 days & 7 days \\
\hline$V P A(0.5 \mathrm{mM})$ & + & + & + & - \\
\hline
\end{tabular}

\section{$(i \alpha, 52$ \\ G $\alpha, 45$}

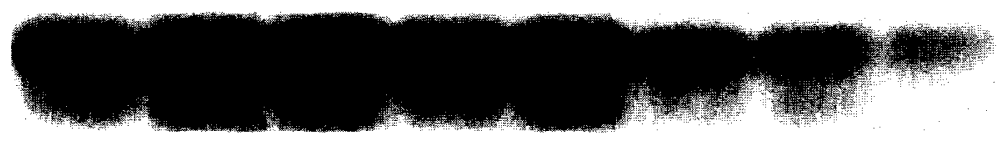

$\left(i \alpha_{i / 11}\right.$

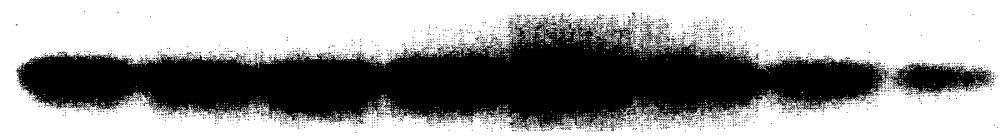

Figure 3. Effects of chronic VPA on toxin catalyzed [32P]ADP-ribosylation. Rat C6 glioma cells were cultured in DMEM and incubated with $0.5 \mathrm{mM}$ VPA for the times indicated. Cells were washed, and cell membranes were prepared as described. Cholera and pertussis toxin catalyzed [ $\left.{ }^{32} \mathrm{P}\right]$ ADP-ribosylations of $\mathrm{G}$-proteins $\left(\mathrm{G}_{\mathrm{s}} 52, \mathrm{G}_{\mathrm{s}} 45\right.$, and $\left.\mathrm{G}_{\mathrm{i} / \mathrm{o}}\right)$ were performed using [ $\left.{ }^{32} \mathrm{P}\right]$ NAD as the substrate according to the methods described. Similar results were also obtained from two or more additional experiments.

orders (McElroy et al. 1992), and VPA at these concentrations was not toxic to $\mathrm{C} 6$ glioma cells. The lack of cytotoxicity in our recent study (Chen et al. 1994) is consistent with previous studies that found no evidence of cytotoxicity in cultured cells, even after 3 weeks of exposure to $1 \mathrm{mM}$ VPA (Regan 1985; Martin and Regan 1988); thus, the effects of VPA on components of the $\beta$-AR-coupled CAMP-generating system do not appear to represent simply the sequelae of in vitro toxicity of VPA on these cells.

Because the clinical antimanic effects of VPA require at least 4 to 5 days (McElroy et al. 1992; Bowden et al. 1994), we investigated the effects of VPA on $\beta$-AR binding parameters over a long time. In contrast to what has been observed with chronic lithium treatment in vivo (Bunney and Garland-Bumney 1987), we found that chronic VPA produced a significant reduction in the density of $\beta$-ARs in C6 glioma cells. [ $\left.{ }^{3} \mathrm{H}\right] \mathrm{CGP}-12177$, a hydrophilic $\beta$-antagonist, is a selective ligand for the study of cell surface $\beta$-ARs in intact cells (Staehelin et al. 1983). Incubation of $\mathrm{C} 6$ cells with VPA produced a time- and concentration-dependent reduction in $\left[{ }^{3} \mathrm{H}\right] \mathrm{CGP}-12177$ binding in intact $\mathrm{C} 6$ cells (Figures $1 \mathrm{~A}$ and $\mathrm{B}$ ). The reduction in $\left[{ }^{3} \mathrm{H}\right] \mathrm{CGP}-12177$ binding was not due to VPA directly interacting with $\beta$-AR binding sites as the presence of VPA in the reaction mixture did not alter $\left[{ }^{3} \mathrm{H}\right] \mathrm{CGP}-12177$ binding to $\beta$-AR.

In order to determine whether the VPA-induced reductions in cell surface $\beta$-ARs were due to true decreases in the numbers of $\beta$-ARs or to the redistribution of $\beta$-ARs from the surface, $\beta$-AR binding experiments were performed in cell membrane preparations and using $\left[{ }^{125} \mathrm{I}\right] \mathrm{ICYP}$ (a lipophilic $\beta$-antagonist) as the radioligand. Chronic incubation of $\mathrm{C} 6$ cells with VPA did not affect the affinity of $\beta-A R(s)$ for either the $\beta$-agonist (ISO) or the $\beta$-antagonists ([ $\left.{ }^{125} \mathrm{I}\right] \mathrm{ICYP}$ and ICI 118.551); by contrast, the total number of $\beta$-ARs $\left(B_{\max }, \beta_{\mathrm{H}}\right.$ plus $\beta_{\mathrm{L}}$ or $\beta_{1}$ plus $\beta_{2}$ ) as well as the numbers of $\beta$-ARs at high- and low-affinity states were significantly decreased (Table 1). Subtype analysis of $\beta$-ARs showed that chronic VPA produced a strikingly selective reduction in $\beta_{1}$-ARs (Table 1). The effects of VPA on $\beta$-ARs do not simply represent nonspecific effects of incubation of these cells with psychotropic drugs, as carbamazepine produces an upregulation of $\beta$-ARs (Chen et al. 1992) whereas lithium is without effect on $\beta$-ARs in these cells (unpublished observations).

As expected, we found the VPA-induced decreases in the density of $\beta$-ARs were accompanied by decreases in receptor-mediated cAMP production in intact $\mathrm{C} 6$ glioma cells. Interestingly, the VPA-induced decrease in ISOstimulated cAMP production ( $52 \%$; Table 2$)$ was greater than in the numbers of $\beta$-ARs (approximately $30 \%$; Figures $1 \mathrm{~A}$ and $\mathrm{B}$; Table 1 ) in intact cells and cell membrane preparations. Chronic VPA incubation also resulted in an attenuation of basal cAMP production, which reached statistical significance in membrane preparations (Table 2). These results suggest that chronic VPA also affects the $\beta-A R / G_{S}$ interaction or postreceptor sites (e.g., on $G_{S}$ and or $\mathrm{AC}$ ). To investigate this more directly, we stimulated the cAMP production system at postreceptor levels with forskolin and $\mathrm{Mn}^{+-}$. Chronic exposure of $\mathrm{C} 6$ cells to VPA resulted in significantly lower increases in levels of cAMP in response to both forskolin (61\% lower) and $\mathrm{MnCl}_{2}$ ( $48 \%$ lower). The data indicate that VPA desensitizes both receptor- and postreceptor-stimulated cAMP production.

To elucidate the mechanisms underlying VPA's effects on postreceptor-stimulated cyclic AMP production at the $G$ protein level, we used immunolabeling with selective antibodies and toxin-catalyzed [32P]ADP-ribosylation to 
A

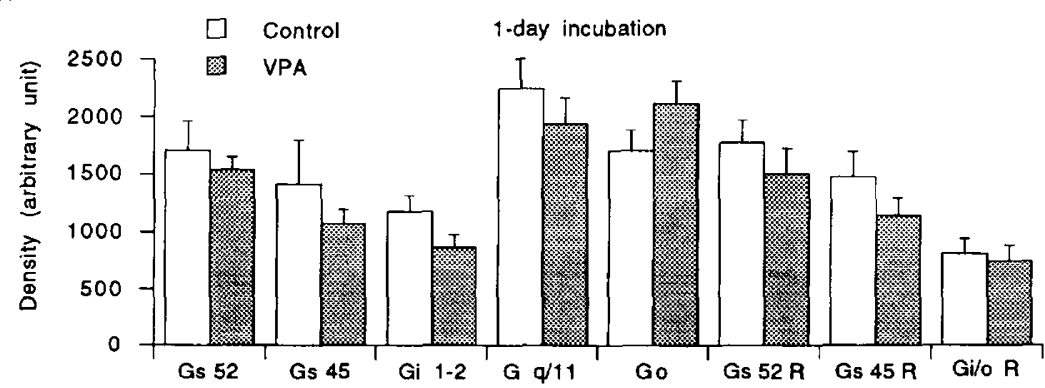

B

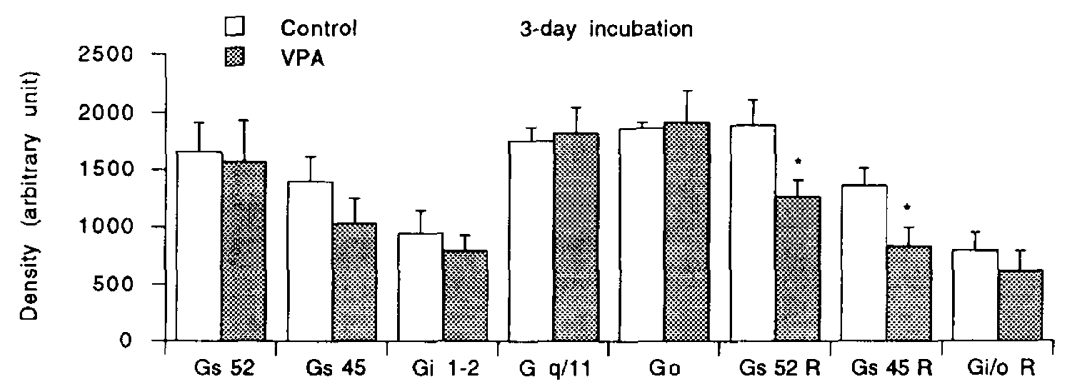

C

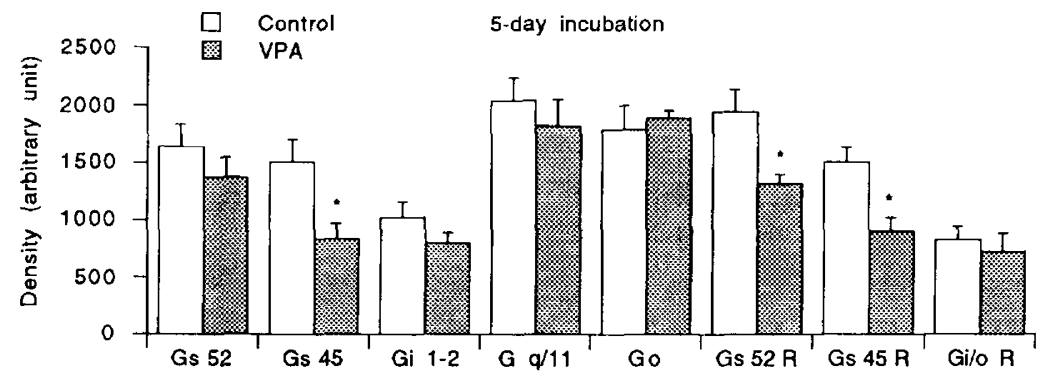

D

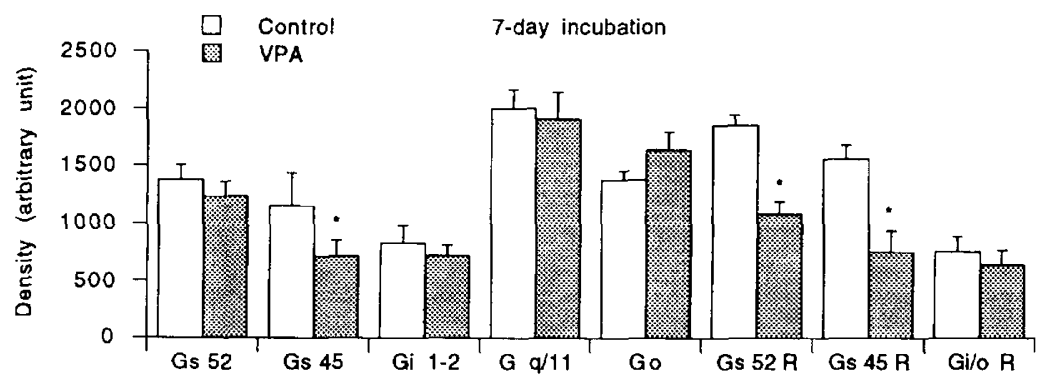

Figure 4. Effects of chronic VPA on the levels of G protein $\alpha$ subunits and toxin catalyzed [32P]ADP-ribosylation. Rat C6 glioma cells were cultured in DMEM and incubated with $0.5 \mathrm{mM}$ VPA for the times indicated. Cells were washed, and cell membranes were prepared as described. Western blotting of $G$-protein $\alpha$ subunits $\left(\mathrm{G}_{\mathrm{s}}, 52, \mathrm{G}_{\mathrm{s}} 45, \mathrm{G}_{\mathrm{i} 1-2}, \mathrm{G}_{\mathrm{q} / 11}\right.$, and $\left.\mathrm{G}_{\mathrm{o}}\right)$ was performed using selective polyclonal antibodies. Cholera and pertussis toxin catalyzed [32P]ADP-ribosylations of G-proteins $\left(G_{s} 52, G_{s} 45\right.$, and $\left.G_{i / 0}\right)$ were performed using [ ${ }^{32} P J N A D$ as the substrate according to the methods described. An aliquot of pooled "standard" C6 membranes was run on one lane of ev'ery gel, and the quantitation was calculated relative to this standard. Values are mean $=S E$ for three to four experiments. ${ }^{*}, p<.05$ compared to control, two-tailed Student's $t$ test.

characterize $G$ proteins. We found that chronic, but not acute, VPA incubation induced a marked decrease in the levels of $G \alpha_{S} 45$ but not any other $G$ protein $\alpha$ subunits examined $\left(G \alpha_{s} 52, G \alpha_{i 1-2}, G \alpha_{(1)}\right.$, or $G \alpha_{q} / 11$; see Figures 2 and 4$)$. The different forms of $G \alpha_{s}$ arise as a result of alternative splicing of a single gene (Bray et al. 1986). These different forms of $\mathrm{G} \alpha_{s}$ also vary on number of phosphorylation sites by protein kinase $\mathrm{C}(\mathrm{PKC})$ and protein $\mathrm{ki}$ - nase A (Bray et al. 1986; Pyne et al. 1992a, and 1992b). In contrast to only reducing the immunolabeling of $\mathrm{G} \alpha_{\mathrm{s}}$, chronic VPA incubation resulted in a decrease in the cholera toxin catalyzed [ ${ }^{32} \mathrm{P}$ ]ADP-ribosylation of both $G \alpha_{\mathrm{s}}$ 52 and $G \alpha_{S} 45$ (Figures 3 and 4). These results suggest that chronic VPA produces a modification of $G \alpha_{\mathrm{s}} 52$, rendering it less susceptible to cholera toxin catalyzed [ $\left.{ }^{32} \mathrm{P}\right] \mathrm{ADP}-$ ribosylation without affecting the absolute levels of the 
protein. It is noteworthy that [32P]ADP-ribosylation labels $G$-protein $\alpha$, which is associated with $\beta \gamma$ subunits and can be activated after receptor stimulation (Birnbaumer et al. 1988). In this context, a decrease in cholera toxin catalyzed [ $\left.{ }^{32} \mathrm{P}\right] \mathrm{ADP}$-ribosylation of G-protein is an indication of reduced $G_{S}$ function. Consistent with the lack of effect on the immunolabeling of $G \alpha_{i 1-2}$ or $G \alpha_{0}$, chronic VPA did not produce marked alterations in pertussis toxin catalyzed [ ${ }^{32} \mathrm{P}$ ]ADP-ribosylation.

In keeping with the decreases in the production of cAMP stimulated by forskolin and the function of $G_{s}$, chronic VPA also produced a $46 \%$ decrease in membrane $\left[{ }^{3} \mathrm{H}\right]$ forskolin binding. $\left[{ }^{3} \mathrm{H}\right]$ forskolin binding reflects the levels not only of AC but also of AC coupled to activated $\mathrm{G} \alpha_{s}$ in the binding mixture (Seamon et al. 1985). In the present study, the decreased binding may be due to the reduction of functional $G_{s}$ after chronic VPA incubation. However, because we also observed VPA-induced decreases in basal and $\mathrm{Mn}^{++}$-stimulated cyclic AMP production, a direct AC activator (Ross and Gilman 1980), it is possible that VPA also affects the amount of $\mathrm{AC}$.

In conclusion, chronic exposure of $\mathrm{C} 6$ glioma cells to VPA produces a coordinate decrease in multiple components of the $\beta$-AR-coupled CAMP-generating system. Thus, chronic VPA produces a decrease in the density of $\beta$-ARs (mainly $\beta_{1}-A R$ ) and reductions in receptor- and postreceptor-stimulated cyclic AMP production, in the immunolabeling of $\mathrm{G} \alpha_{s} 45$, in cholera toxin catalyzed [ $\left.{ }^{32} \mathrm{P}\right] \mathrm{ADP}$-ribosylation of both $\mathrm{G} \alpha_{\mathrm{s}} 52$ and $\mathrm{G} \alpha_{\mathrm{s}} 45$, and in $\left[{ }^{3} \mathrm{H}\right]$ forskolin binding sites. The mechanism(s) by which VPA produces these effects is unknown. However, it is noteworthy that we have recently demonstrated that VPA has marked effects on PKC (Chen et al. 1994) and PKC directly phosphorylates $\beta-A R, G \alpha_{S}$, and $A C$ in vitro (Kelleher et al. 1984; Yoshimasa et al. 1987; Pyne et al. 1992). Stimulation of PKC downregulates and desensitizes $\beta$-ARs in C6 cells (Fishman et al. 1987), as does chronic VPA treatment in the present study. Stimulation of PKC also abolishes thyrotropin- and forskolin-induced increases in levels of $G x_{s}$-protein and mRNA in pig thyroid cells (Dib et al. 1994). Whatever the underlying mechanism(s), given the evidence for the involvement of the noradrenergic system in the pathophysiology of manicdepressive illness, as well as the reported effects of lithium on the $\beta-A R / G_{s} / A C$ system, these long-term changes induced by chronic VPA treatment may contribute to its therapeutic efficacy and are worthy of further study.

\section{REFERENCES}

Andersen PH, Geisler A (1984): Lithium inhibition of forskolin-stimulated adenylate cyclase. Neuropsychobiology $12: 1-3$

Bourgeois BFD (1989): Valproate: Clinical Use. In Levy R,
Mattson R, Meldrum B, Penry JK, Kreifuss FE (eds), Antiepileptic, ed 3. New York, Raven, pp 633-641

Bowden CL, Brugger AM, Swenn AA, Calabrese JR, Janicak PG, Petty F, Dilsaver SC, Davis JM, Rush AI, Small JG (1994): Efficacy of divalproex vs lithium and placebo in the treatment of mania. JAMA 271:918-924

Bradford MM (1968): A rapid and sensitive method for the quantitation of microgram quantities of protein utilizing the principle of protein-dye binding. Anal Biochem $72: 248-254$

Bray P, Simons C, Guo B, Puckett C, Kamholz I, Spiegel A, Nirenberg M (1986): Human cDNA clones for four species of $\mathrm{G} \alpha_{\mathrm{s}}$ signal transduction protein. Proc Natl Acad Sci U S A 83:8893-8897

Bunney WE Jr, Garland-Bunney B (1987): Mechanisms of action of lithium in affective illness: Basic and clinical implications. In Meltzer HY (ed), Psychopharmacology: The Third Generation of Progress. New York, Raven, pp 553-565

Chen G, Hough C, Manji HK, Chuang DM, Potter WZ (1992): Desipramine and Carbamazepine modulate $\beta$ adrenergic receptors ( $\beta A R s$ ) and $\beta A R$ mRNA in vitro. Clin Pharmacol Ther 51:190

Chen G, Manji HK, Hawver DB, Wright CB, Potter WZ (1994): Chronic sodium valproate selectively decreases protein kinase $C$ alpha and epsilon in vitro. J Neurochem 63:23612364

Dib K, Delemer B, el Jamali A, Haye B, Jacquemin C, Correze C (1991): 12-O-tetradecanoyl-phorbol-13-acetate (TPA) counteracts the CAMP up-regulation of the expression of the stimulatory guanine nucleotide binding protein (Gs alpha) and Gs alpha messenger RNA in cultured pig thyroid cells. Mol Cell Endocrinol 99:229-235

Fishman PH, Finberg JP (1987): Effect of the tricyclic antidepressant desipramine on beta-adrenergic receptor in cultured rat C6 glioma cells. J Neurochem 49:282-289

Fishman PH, Sullivan M, Patel J (1987): Down-regulation of protein kinase $C$ in rat $C 6$ glioma cells: Effects on the betaadrenergic receptor-coupled adenylate cyclase. Biochem Biophys Res Commun 144:620-627

Geisler A, Klysner R, Andersen PH (1985): Influence of lithium in vitro and in vivo on the catecholamine-sensitive cerebral adenylate cyclase systems. Acta Pharmacol Toxicol (Copen) 56:80S-97S

Gilman AG (1987): G proteins: transducers of receptor-generated signals. Ann Rev Biochem 56:615-649

Goodwin FK, Jamison KR (1990): Manic-Depressive Illness. New York, Oxford University Press

Hsiao JK, Manji HK, Chen G, Bitran JA, Risby ED, Potter WZ (1992): Lithium administration modulates platelet $G_{i}$ in humans. Life Sci 50:227-233

Kelleher DJ, Pessin JE, Ruoho AE, Johnson GL (1984): Phorbol ester induces desensitization of adenylate cyclase and phosphorylation of the beta-adrenergic receptor in turkey erythrocytes. Proc Natl Acad Sci U S A 81:4316-4320

Laemmli UK (1970): Cleavage of structural proteins during the assembly of the head of the bacteriophage. Nature 227:680-685

Laurenza A, Seamon KB (1991): high-affinity binding sites for $\left[{ }^{3} \mathrm{H}\right]$ forskolin. Meth Enzymol 195:52-65

Löscher W (1993): Effects of the antiepileptic drug valproate 
on metabolism and function of inhibitory and excitatory amino acids in the brain. Neurochem Res 18:485-502

Manji HK (1992): G Proteins: Implications for Psychiatry. Am J Psychiatry 149:746-760

Manji HK, Chen G, Bitran JA, Gusor'sky F, Potter WZ (1991a): Chronic exposure of $\mathrm{C} 6$ glioma cells to desipramine desensitizes beta-adrenoceptors, but increases $\mathrm{K}_{\mathrm{L}} / \mathrm{K}_{\mathrm{H}}$ ratio. Eur J Pharmacol 206:159-162

Manji HK, Chen G, Bitran J, and Potter WZ (1991b): Downregulation of beta receptors by desipramine in vitro involves PKC/phospholipase A2. Psychopharmacol Bull $27: 247-253$

Manji HK, Risby ED, Hsiao JK, Chen G, Potter WZ (1992): Effects of lithium on signal transduction in humans. Clin Neuropharmacol 15:608A-609A

Manji HK, Chen G, Shimon H, Hsiao JK, Potter WZ, Belmaker RH (1995a): Guanine nucleotide binding proteins in bipolar affective disorder: Effects of long-term lithium treatment. Arch Gen Psychiatry 52:135-144

Manji HK, Rudorfer MV, Potter WZ (1995b): Affective Disorders and Adrenergic function. In Cameron OG (ed), Adrenergic Dysfunction and Psychobiology. Washington DC, American Psychiatric Press, pp 365-401

Masana MI, Bitran JA, Hsiao JK, Potter WZ (1992): In vivo evidence that lithium inactivates $G_{i}$ modulation of adenylate cyclase in brain. J Neurochem 59:200-205

Martin ML, Regan CM (1988): The anticonvulsant sodium ralproate specifically induces the expression of a rat glial heat shock protein which is identified as the collagen type IV receptor. Brain Res 459:131-137

McElroy SL, Keck PE Jr, Pope HG Jr, Hudson JI (1992): Valproate in the treatment of bipolar disorder: Literature review and clinical guidelines. J Clin P'sychopharmacol $12: 42 S-52 S$

Mork A, Geisler A (1987a): Effects of lithium on calmodulinstimulated adenylate cyclase activity in cortex membrane from rat brain. Pharmacol Toxicol 60:17-23

Mork A, Geisler A (1987b): Mode of action of lithium on the catalytic unit of adenylate cyclase from rat brain. Pharmacol Toxicol 60:241-248

Mork A, Geisler A (1989a): The effects of lithium in vitro and ex vivo on adenylate cyclase in brain are exerted by distinct mechanisms. Neuropharmacology 28:307-311

Mork A, Geisler A (1989b): Effects of GTP on hormone-stimulated adenylate cyclase activity in cerebral cortex, striatum, and hippocampus from rats treated chronically with lithium. Biol Psychiatry 26:279-288

Munson PJ (1983): LIGAND: A computerized analysis of ligand binding data. Methods Enzvmol 92:543-576

New man ME, Belmaker RH (1987): Effects of lithium in vitro and ex vivo on components of the adenylate cyclase system in membranes from the cerebral cortex of the rat. Neuropharmacology 26:211-271

Nishizuka Y (1992): Intracellular signaling by hydrolysis of phospholipids and activation of protein kinase $C$. Science 258:607-614

Post RM, Weiss SR, Chuang DM (1992): Mechanisms of action of anticonvulsants in affective disorders: Comparisons with lithium. J Clin Psychopharmacol 12:23S-35S
Potter WZ, Rudorfer MV, Goodwin FK (1987): Biological Findings in Bipolar Disorders. In Hales RE and Frances AJ (eds), APA Annual Review. Washington, DC, American Psychiatric Press, pp 32-60

Pyne NJ, Freissmuth M, Palmer S (1992a): Phosphorylation of the recombinant spliced variants fo the alpha-sub-unit of the stimulatory guanine-nucleotide binding regulatory protein $\left(G_{s}\right)$ by the catalytic sub-unit of protein kinase $A$. Biochem Biophys Res Commun 86:1081-1086

Pyne NJ, Freissmuth M, Palmer S (1992b): Phosphorylation of the spliced variants forms of the recombinant stimulatory guanine-nucleotide-binding regulatory protein $\left(G_{S}\right.$ alpha) by protein kinase C. Biochem J 285:333-338

Regan CM (1985): Therapeutic levels of sodium valproate inhibit mitotic indices in cells of neural origin. Brain Res 347:394-398

Robishaw JD, Smigel MD, Gilman AG (1986): Molecular basis for two forms of the $G$ protein that stimulates adenylate cyclase. J Biol Chem 261:9587-9890

Rogawski MA, Porter RJ (1990): Antiepileptic drugs: Pharmacological mechanisms and clinical efficacy with consideration of promising development stage compounds. Pharmacol Rev 42:223-286

Ross EM, Gilman AG (1980): Biochemical properties of hormone-sensitive adenylate cyclase. Ann Rev Biochem 49: $533-564$

Seamon KB, Vaillancourt R, Daly JW (1985): Modulation of forskolin binding to rat brain membranes. J Cyclic Nucleotide Protein Phosphor Res 10:535-549

Simonds WF, Goldsmith PK, Woodward CJ, Unson CG, Spiegel AM (1993): Receptor and effector interactions of $G_{s}$. Functional studies with antibodies generated to the alpha s carboxyl-terminal decapeptide. FEBS Lett 249:189-194

Staehelin M, Hertel C (1983): ['H]CGP-12177, a beta-adrenergic ligand suitable for measuring cell surface receptors. J Recept Res 3:35-43

Tang WJ, Gilman AG (1991): Type-specific regulation of adenylyl cyclase by $G$ protein beta gamma subunits. Science 254:1500-1503

Thiele EA, Eipper BA (1990): Effect of secretagogues on components of the secretory system in AtT-20 cells. Endocrinology 126:809-817

Tiong AH, Richardson JS (1989): Characterization of rat cerebral cortical beta adrenoceptor subtypes using (-)-[ $\left.{ }^{125} \mathrm{I}\right]-$ iodocyanopindolol. J Recept Res 9:495-508

Wilder BJ (1992): Pharmacokinetics of Valproate and Carbamazepine. J Clin Psychopharmacol 12:64S-68S

Yoshimasa T, Sibley DR, Bouvier M, Lefkowitz RJ, Caron MG (1987): Cross-talk between cellular signalling pathways suggested by phorbol-ester-induced adenylate cyclase phosphorylation. Nature 327:67-70

Young LT, Li PP, Kish SJ, Siu KP, Kamble A, Hornykiewicz O, Warsh JJ (1993): Cerebral cortex $G_{k}$ alpha protein levels and forskolin-stimulate cyclic AMP formation are increased in bipolar affective disorder. J Neurochem 61:890-898

Young LT, Li PP, Kamble A, Siu KP, Warsh JJ. (1994): Mononuclear leukocyte levels of $G$ proteins in depressed patients with bipolar disorder or major depressive disorder. Am J Psychiatry 151:594-596 